\title{
Hubungan Faktor Manusia dan Lingkungan Fisik Rumah dengan Kejadian Penyakit Tuberkulosis Paru di Wilayah Kerja Puskesmas Cilongok I Tahun 2016
}

\author{
Candra Raditya $^{1)}$, Agus Subagiyo ${ }^{2)}$, Nur Hilal ${ }^{3)}$ \\ Jurusan Kesehatan Lingkungan, Politeknik Kesehatan Kemenkes Semarang, \\ Jl.Raya Baturaden KM 12 Purwokerto, Indonesia
}

\begin{abstract}
Abstrak
Penyakit berbasis lingkungan masih menjadi masalah kesehatan masyarakat dunia, salah satunya Tuberkulosis. Penyakit Tuberkulosis adalah penyakit infeksi menular yang disebabkan oleh bakteri Mycobacterium tubercolusis. Kabupaten Banyumas tahun 2014 tercatat 3 Puskesmas dengan angka penemuan kasus penyakit Tuberkulosis Paru tertinggi yaitu Puskesmas Kembaran II, Puskesmas Cilongok I dan Puskesmas Lumbir. Tujuan dari penelitian ini adalah mengetahui hubungan faktor manusia dan lingkungan fisik rumah dengan kejadian Tuberkulosis Paru di Wilayah Kerja Puskesmas Cilongok I tahun 2016. Penelitian ini bersifat observasional dengan menggunakan metode case control. Sampel sebanyak 60 orang, terdiri dari 30 kasus dan 30 kontrol. Variabel yang diteliti meliputi status gizi, kontak penderita, perilaku, pencahayaan, kelembababan, suhu, luas ventilasi jenis lantai, jenis dinding dan kepadatan penghuni. Analisis data menggunakan analisis univariat, bivariat dan multivariat. Hasil analisis menggunakan uji statistik Chi Squre, OR dengan CI 95\%, $\alpha ; 0,05$ dan uji Regresi Logistik dengan metode Backward LR CI 95\% dan a : 0,25. Hasil penelitianini adalah status gizi nilai ( $p=0,009 ;$ OR 4,667), kontak penderita ( $p=0,000 ;$ OR 9,333), perilaku $(p=0,43)$, pencahayaan ( $p=0,038 ;$ OR 3,455), kelembaban nilai $(p=0,295)$, suhu $(p=1,000)$, luas ventilasi $(p=0,472)$, jenis lantai $(p=0,333)$, jenis dinding $(p=0,792)$ dan kepadatan penghuni $(p=0,100)$.Kesimpulan dari penelitian ini adalah ada hubungan antara status gizi, kontak penderita dan pencahayaan dengan kejadian Tb Paru, dan kontak penderita merupakan variabel paling dominan. Disarankan penderita Tb Paru harus menjaga kontak terhadap keluarga untuk mencegah penularan terhadap keluarga serumah atau lingkungan rumah, melakukan upaya perbaikan gizi, membuka jendela kamar dan menambah lubang ventilasi agar cahaya dapat masuk dalam ruang kamar.
\end{abstract}

Kata kunci : manusia ; lingkungan fisik rumah ; tb paru

\begin{abstract}
Environmental based diseases are still be health's problem for all people in the world, one of them is Tuberculosis. Tuberculosis is a contagious infectious disease caused by the bacterium Mycobacterium tubercolusis.Banyumas Regency in 2014 was recorded that 3 Puskesmas had the most finding cases level of Tuberculosis they were Puskesmas Kembaran II, Puskesmas Cilongok I, and Puskesmas Lumbir. This research is observational and uses case control method. The sample was 60 people, who 30 cases and 30 controls. Variables which were examined were nutrient status, patient contacts, behavior, lighting, humidity, temperature, and width of floor ventilation type, type of wall and population density. Data analysis used univariate, bivariate, and multivariate analysis. All of the calculation used computer program and analyzed by chi square statistics test, OR with CI 95\%, $\alpha ; 0,05$ and Logistic Regression test by Backward LRmethod CI 95\% and $\alpha: 0,25$. The result of this research is that nutrient status value ( $p=0,009 ;$ OR 4,667), patient contact $(p=0,000 ;$ OR 9,333), behavior $(p=0,43)$,lighting ( $p=$ $0,038$; OR 3,455), humidity ( $p=0,295)$, temperature $(p=1,000)$, width of ventilation $(p=0,472)$, type of floor ( $p=$ $0,333)$, type of wall $(p=0,792)$ and population density $(p=0,100)$. The conclusion of this research is that there was no correlation between nutrient status, patient contact and lighting with Tb case, and patient contact was he most dominant variable. The researcher suggests to Tb patients to keep contact to family for preventing way of spreading the disease in family and environment, do nutrient rehabilitative effort, open room windows and add ventilation in order to get more sun light.
\end{abstract}

Keyword : human ; houses physical environment ; pulmonary tb

\section{PENDAHULUAN}

Penyakit berbasis lingkungan masih menjadi masalah kesehatan masyarakat dunia, salahsatunya Tuberkulosis. Penyakit Tuberkulosis adalah infeksi menular yang disebabkan oleh bakteri Mycobacterium tubercolusis.Tuberkulosis 
merupakan masalah kesehatan, baik dari sisi angka kematian, angka kejadian penyakit, maupun diagnosis dan terapinya. Tuberkulosis Paru merupakan penyakit yang pengendaliannya menjadi komitmen global dalam program MDGs.

Hasil penelitian Chandra W (2004), faktor resiko yang paling berperan terhadap kejadian TB Paru pada kasus kontak adalah usia, jenis kelamin, status gizi, status ekonomi, kondisi rumah, perilaku, dan pekerjaan. Faktor yang mempengaruhi kondisi rumah terdiri dari kepadatan hunian, jenis lantai, ventilasi, dan kelembaban.

Kabupaten Banyumas terdapat 39 Puskesmas yang tersebar di 19 Kecamatan. Tahun 2014 tercatat 3 Puskesmas dengan angka penemuan kasus penyakit Tuberkulosis Paru BTA (+) tertinggi yaitu Puskesmas Kembaran II, Puskesmas Cilongok I dan PuskesmasLumbir.Puskesmas Cilongok I mengalami peningkatan angka penemuankasus TB Paru BTA (+) 3 tahun terakhir dari tahun 2012 hingga tahun 2014 dengan rincian tahun 2012 sebanyak 22 kasus, 201324 kasus, dan 201442 kasus. Pendataan sarana kesehatan lingkungan untuk kualitas fisik rumah sehat3 tahun terkahir dalam kondisi tidak memenuhi kriteria rumah sehat yaitu tahun 2012 (16 \%), 2013 (27,24\%), 2014 (18,89\%), dibanding tahun 2012 prosentase rumah yang tidak memenuhi kriteria rumah sehat mengalami peningkatan pada tahun 2013 dan 2014.

Tujuan dari penelitian ini adalah mengetahui hubungan faktor manusia dan lingkungan fisik rumah dengan kejadian Tuberkulosis Paru di Wilayah Kerja Puskesmas Cilongok I.

\section{BAHAN DAN METODE}

Variabel bebas pada penelitian ini adalah status gizi, kontak penderita, perilaku, pencahayaan, kelembaban, suhu, luas ventilasi jenis lantai, jenis dinding dan kepadatan penghuni sedangkan variabel terikatnya adalah Kejadian Tuberkulosis Paru BTA (+) pada orang dewasa. Jenis penelitian ini adalah observasional dengan pendekatancase control. Populasi dalam penelitian ini semua responden atau penderitaTB Paru yang didiagnosa BTA (+) dan (-) oleh tenaga kesehatan dokter atau institusi kesehatan dengan jumlah sampel 60 responden 30 kontrol dan 30 kasus. Pengumpulan data menggunakan kuisioner, ceklist, hygrometer, luxmeter, roll meter dan timbangan badan.Analisis univariat menggunakan distribusi frekuensi, bivariat menggunakan uji statistik Chi Squredan multivariat menggunakan Regresi Logistik dengan metode Backward LR.

\section{HASIL DAN PEMBAHASAN} Analisis Univariat

\section{Status Gizi}

Hasil dari pengukuran dan perhitungan 60 responden status gizi yang dikategorikan normal pada kelompok kasus yaitu sebanyak 9 (30\%) lebih sedikit dari kelompok kontrol 20 (66,7\%) dan pada kategori tidak normal pada kelompok kasus sebanyak 21 (70\%) lebih banyak dibanding kontrol yaitu 10 (33,3\%).

\section{Kontak Penderita}

Hasil dari wawancara responden yang tidak kontak atau tidak tinggal bersama dengan penderita TB Paru pada kelompok kasus yaitu sebanyak 6 (20\%) lebih sedikit dari kelompok kontrol 21 (70\%), dan pada kategori tidak baik pada kelompok kasus sebanyak 24 (80\%) lebih banyak dibanding kontrol yaitu 9 (30\%).

\section{Perilaku}

Hasil dari wawancara dan perhitungan 60 responden perilaku yang dikategorikan baik pada kelompok kasus yaitu sebanyak 10 (33,3\%) lebih sedikit dari kelompok kontrol $14(46,7)$, dan pada kategori tidak baik pada kelompok kasus sebanyak $20(66,7 \%)$ lebih banyak dibanding kontrol yaitu 16 (53,3\%).

\section{Pencahayaan}

Pada tabel 3 menunjukkan bahwa hasil dari pengukuran 60 rumah responden pencahayaan yang memenuhi syarat pada kelompok kasus yaitu sebanyak 11 (36,7\%) lebih sedikit dari kelompok kontrol 20 (63,6\%), dan pada kategori tidak memenuhi syarat pada kelompok kasus sebanyak 19 (63,3\%) lebih banyak dibanding kontrol yaitu $10(33,3 \%)$.

\section{Kelembaban}

Hasil pengukuran kelembaban rumah responden yang memenuhi syarat pada kelompok kasus yaitu sebanyak 10 (33,3\%) lebih sedikit dari kelompok kontrol 15 (50\%), dan tidak memenuhi syarat kelompok kasus sebanyak 20(66,7\%) lebih banyak dibanding kontrol yaitu 15 (50\%).

\section{Suhu}

Hasil pengukuran suhu rumah responden yang memenuhi syarat pada kelompok kasus yaitu sebanyak 29 (96,7\%) lebih banyak dari kelompok kontrol 28 (93,3\%), dan suhu rumah yang tidak memenuhi syarat pada kelompok kasus sebanyak $1(3,3 \%)$ lebih sedikit dibanding kontrol yaitu 2 $(6,7 \%)$.

\section{Luas Ventilasi}

Hasil dari pengukuran dan perhitungan 60 rumah responden luas ventilasi yang memenuhi syarat pada kelompok kasus yaitu sebanyak 24 (80\%) lebih sedikit dari kelompok kontrol 27 (90\%), dan rumah yang luas ventilasi tidak memenuhi syarat pada kelompok kasus sebanyak 6 (20\%) lebih banyak dibanding kontrol yaitu 3 (10\%).

Jenis Lantai

Hasil observasi lantai rumah responden yang kedap air pada kelompok kasus yaitu sebanyak 22 
(73,3\%) lebih sedikit dari kelompok kontrol 26 (86,7\%), dan lantai yang tidak kedap air pada kelompok kasus sebanyak 8 (26,7\%) lebih banyak dibanding kontrol yaitu 4 (13,3\%).

\section{Jenis Dinding}

Hasil dari observasi 60 rumah responden jenis dinding yang dikategorikan memenuhi syarat atau terbuat dari semen batubata pada kelompok kasus yaitu sebanyak 17 (56,7\%) lebih sedikit dari kelompok kontrol 19 (63,3\%), dan pada kategori tidak memenuhi syarat/ terbuat dari anyaman bambu/ kayu pada kelompok kasus sebanyak 13 (43,3\%) lebih banyak dibanding kontrol yaitu 11 (36,7\%).

Kepadatan Penghuni

Hasil dari wawancara dan perhitungan 60 responden kepadatan penghuni yang memenuhi syarat pada kelompok kasus yaitu sebanyak 28 (93,3\%) lebih banyak dari kelompok kontrol 27 (90\%), dan pada kategori tidak memenuhi syarat pada kelompok kasus sebanyak 2 (6,7\%) lebih sedikit dibanding kontrol yaitu 3 (10\%).

\section{Analisis Bivariat \\ Status Gizi}

Hasil penelitian status gizi responden menggunakan alat berupa timbangan badan dan roll meter status gizi responden yang dikategorikan tidak normal sebanyak 51,7 \% sedangkan dikategorikan normal pada kelompok kasus sebanyak $30 \%$ dan kelompok kontrol $66,7 \%$.

Dalam analisa dengan uji statistik chisquare diperoleh hasil p value 0,009 yang berarti lebih kecil dari 0,05. Oleh karena p value lebih kecil dari 0,05 maka H0 diterima dan OR 4,667, dengan demikian dinyatakan bahwa status gizi merupakan faktor risiko kejadian tuberkulosis paru atau ada hubungan yang signifikan antara status gizi responden dengan kejadian Tuberkulosis Paru, artinya seseorang dengan status gizi kurang atau tidak normal mempunyai risiko meningkatkan kejadian tuberkulosis paru sebanyak 4,667 kali lebih besar dibanding dengan status gizi baik atau normal.

Hasil penelitian menunjukankesesuaian dengan penelitian Afiyah Sri Harnany (2013) yang menunjukkan hasil $\mathrm{p}$ value $=0,000 \mathrm{OR}=$ 7,583 CI 3,406- 16,882 bahwa orang dengan BMI $<18,5$ mempunyai risiko 7,583 kali lebih besar untuk menderita Tuberkulosis Paru dibanding orang dengan $\mathrm{BMI} \geq 18,5$.

\section{Kontak Penderita}

Proporsi kasus yang mempunyai riwayat kontak dengan penderita ada 80\% lebih besar dibanding pada kelompok kontrol (30\%). Secara statistik hasil analisa menunjukkan $\mathrm{p}=0,000$ dan $\mathrm{OR}=9,333$ dengan CI 95\% $=2,847<\mathrm{OR}<30,602$ sehingga bermakna karena $\mathrm{p}<0,05$ dengan demikian dinyatakan bahwa kontak penderita merupakan faktor risiko kejadian Tuberkulosis Paru atau ada hubungan antara kontak penderita dengan kejadian Tuberkulosis Paru.

Riwayat kontak merupakan hal yang penting dalam penelitian penyakit Tuberkulosis Paru. Dalam etiologi penyakit tuberkulosis, kuman Mycobacterium tuberculosis berukuran sangat kecil, bersifat aerob, dapat bertahan hidup lama dalam sputum kering, ekskreta lain dan dengan mudah dapat dieksresikan melalui inhalasi butir sputum lewat batuk, bersin maupun bicara (droplet infection). Sehingga kontak yang sering dengan penderita tuberkulosis aktif akan menyebabkan infeksi atau paparan paparan orang yang sehat.

Seseorang yang tinggal di rumah terdapat orang yang mengidap Tuberkulosis aktif atau yang memiliki risiko Tuberkulosis, akan memiliki risiko sama tingginya untuk mengidap Tuberkulosis. Menurut Rosmayudi (2010), sumber penularan yang paling berbahaya adalah penderita orang dewasa yang menderita Tuberkulosis dengan kavitas (lubang pada paruparu). Kasus seperti ini sangat infeksius dan dapat menularkan penyakit melalui batuk, bersin dan percakapan. Semakin sering dan lama kontak, makin besar pula kemungkinan terjadi penularan.

Hasil penelitian ini sama dengan penelitian yang dilakukan oleh Afiyah Sri Harnany (2013) yaitu OR = 4,387 CI 0,897- 21,454p value= 0,049 yang menyatakan kontak penderita 4,387 kali berisiko tertular tuberklosis paru dibandingkan dengan yang tidak kontak dengan penderita tuberkulosis paru.

\section{Perilaku}

Proporsi perilaku tidak baik lebih banyak kasus (66,7,\%) dibanding pada kontrol (53,3\%). Secara statistik hasil analisa menunjukkan $\mathrm{p}=$ 0,43 dan $\mathrm{OR}=1,750$ dengan $\mathrm{CI} 95 \%=$ $0,616<\mathrm{OR}<4,973$ sehingga tidak bermakna karena p > 0,05 dengan demikian dinyatakan bahwa perilaku tidak merupakan faktor risiko kejadian tuberkulosis paru atau tidak ada hubungan yang signifikan antara perilaku responden dengan kejadian Tuberkulosis Paru.

Hasil penelitian ini tidak sesuai dengan penelitian Setiawan Dwi Antoro (2010) yang menyatakan bahwa perilaku merupakan faktor risiko kejadian tuberkulosis paru atau ada hubungan antara perilaku dengan kejadian tuberkulosis paru, dengan nilai OR sebesar 2,606 dan $\mathrm{p}$ value $=0,031$.

\section{Pencahayaan}

Pengukuran pencahayaan rumah responden menggunakan alat berupa LUX meter dengan berlandaskan pada peraturan RI No.1077/MENKES/PER/V/2011 tentang persyaratan pencahayaan rumah yang baik yaitu minimum 60 LUX dan tidak menyilaukan. Cahaya matahari sangat penting masuk di dalam 
rumah, karena dapat membunuh bakteri-bakteri pathogen, misalnya bakteri penyebab penyakit Pneumonia, ISPA maupun TBC. Fungsi jendela disamping sebagai ventilasi juga sebagai jalan masuknya cahaya. Lokasi penempatan jendela harus ditengah-tengah tembok cahaya yang masuk ke dalam rumah ataupun ruangan lebih lama menyinari lantai (Suryanto 2003).

Proporsi kasus yang mempunyai rumah dengan pencahayaan tidak memenuhi syarat/ (<60Lux dan>120Lux) pada kelompok kasus $(63,3 \%)$ lebih besar dibanding pada kelompok kontrol (33,3\%). Secara statistik hasil analisa menunjukkan $\mathrm{p}=0,038$ dan $\mathrm{OR}=3,455$ dengan CI $95 \%=1,195<0 R<9,990$ sehingga bermakna karena $\mathrm{p}<0,05$ dengan demikian dinyatakan bahwa pencahayaan rumah merupakan faktor risiko kejadian Tuberkulosis Paru atau ada hubungan antara pencahayaan dengan kejadian Tuberkulosis Paru dan rumah responden penderita Tuberkulosis Paru BTA (+) yang memiliki kondisi pencahayaan yang tidak memenuhi syarat berisiko 3,455 kali tertular Tuberkulosis Paru dibandingkan rumah responden yang mempunyai pencahayaan yang baik.

Pencahayaan rumah merupakan variabel pendukung, hal ini di pengaruhi karena pencahayaan yang masuk ke medium tertentu maka sebagian gelombang dipantulkan oleh permukaan, sisanya akan menembus medium dan sebagian yang menembus tersebut akan diserap dan sebagian lagi diteruskan sebagaimana hukum termodinamika 1 (Aris Santjaka, 2013). Cahaya matahari yang masuk dalam ruangan dapat meningkatkan suhu dan menurunkan kelembaban udara. Seperti prinsip termoninamika yaitu perubahan suhu terjadi karena perubahan aliran panas dan usaha yang dilakukan (Aris Santjaka, 2013).

Pengukuran pencahayaan dilakukan di kamar tidur responden dan pencahayaan yang digunakan pada saat penelitian ini dilakukan yaitu pencahayaan alami matahari, karena penelitian ini dilaksanakan pada pagi hingga siang hari.

Hasil penelitian ini sesuai dengan penelitian yang telah dilakukan oleh Aristatika (2011) dan Amalia Kartika (2015) yang menyatakan bahwa ada hubungan pencahayaan dengan kejadian Tuberkulosis Paru. Kondisi pencahayaan merupakan faktor risiko yang cukup signifikan hal ini dapat dilihat dari penelitian diatas, dengan pencahayaan yang kurang maka perkembangan kuman Tuberkulosis Paru akan meningkat karena cahaya mataharimerupakan salah satu faktor yang dapat membunuh kuman TB Paru, sehingga jika pencahayaan baik atau memenuhi syarat maka penularan dan perkembangbiakan kuman bisa dicegah.

Hasil observasi di lapangan salah satu penyebab kurangnya cahaya yang masuk dalam rumah terutama pada kamar karena ada beberapa rumah responden yang belum ada jendela pada kamar atau ada jendela kamar namun tidak dibuka pada saat siang hari.

\section{Kelembaban}

Pengukuran kelembaban rumah responden menggunakan alat berupa Hygrometer digital dengan berlandaskan peraturan RI No.1077/MENKES/PER/V/ 2011 tentang persyaratan kelembaban rumah yaitu 40-60\%. Rumah dengan kelembaban relatif $85 \%$ merupakan kondisi dimana mikroorganisme dapat tumbuh. Mudehir (2002), kelembaban rumah dapat dipengaruhi oleh kontruksi rumah yang tidak baik seperti jenis dinding dan jenis lantai, ventilasi yang kurang serta pencahayaan yang minim.

Proporsi kasus yang mempunyai rumah dengan kelembaban tidak memenuhi syarat/ ( $<40 \%$ dan $>60 \%$ ) pada kelompok kasus $(66,7 \%)$ lebih besar dibanding pada kelompok kontrol (50,3\%). Secara statistik hasil analisa menunjukkan $\mathrm{p}=0,295$ dan $\mathrm{OR}=2,000$ dengan CI $95 \%=0,705<$ OR $<5,677$ sehingga tidak bermakna karena $\mathrm{p}>0,05$ dengan demikian dinyatakan bahwa kelembaban rumah bukan merupakan faktor risiko kejadian Tuberkulosis Paru atau tidak ada hubungan yang signifikan antara kelembaban dengan kejadian Tuberkulosis Paru.

Hasil penelitian ini tidak sesuai dengan penelitian yang telah dilakukan oleh Aristatika (2011) dengan $p$ value $=0,004$ yang artinya ada hubunganantara kelembaban dengan kejadian Tuberkulosis Paru. Dalam penelitian ini kelembaban rumah sebagai variabel pendukung karena dapat dipengaruhi oleh beberapa hal seperti lingkungan rumah yang tidak memenuhi syarat atau oleh cuaca. Pada musim hujan kelembaban akan meningkat namun bila kondisi rumah baik seperti cahaya matahari dapat masuk, tidak terdapat genangan air, ventilasi udara yang cukup dapat mempertahankan kelembaban dalam rumah (Lindawaty, 2010).

Kelembaban yang tinggi dapat meningkatkan berkembangnya bakteri penyebab penyakit salah satunya adalah Mycobacterium tuberculosis. Hasil observasi di lapangan, sebagian besar responden baik kasus maupun kontrol memiliki kebiasaan tidak pernah membuka jendela baik jendela ruang keluarga maupun jendela kamar tidur, kontruksi rumah yang tidak memenuhi syarat seperti jenis lantai dan dinding tidak memenuhi syarat kemudian ventilasi rumah responden masih banyak yang tidak memenuhi syarat kurang mendapatkan sinar matahari yang masuk didalam ruangansehingga menyebabkan kelembabanyang berlebih.

\section{Suhu}


Hasil penelitian suhu rumah responden menggunakan alat berupa termometer ruang ratarata antara $29^{\circ} \mathrm{C}$. Hasil tersebut menunjukkkan bahwa suhu rumah responden memenuhi syarat kesehatan perumahan. Berlandaskan pada peraturan RI No.1077/MENKES/PER/V/2011 tentang persyaratan suhu rumah yang memenuhi syarat yaitu $18^{\circ} \mathrm{C}-30^{\circ} \mathrm{C}$.

Proporsi kasus yang suhu rumahnya tidak memenuhi syarat/ $\left(<18^{0} \mathrm{C}\right.$ dan $\left.>30^{\circ} \mathrm{C}\right)$ pada kelompok kasus (3,3\%) lebih kecil dibanding pada kelompok kontrol (6,7\%). Secara statistik hasil analisa menunjukkan $\mathrm{p}=1,000$ dan $\mathrm{OR}=$ 0,483 dengan CI $95 \%=0,041<\mathrm{OR}<5,628$ sehingga tidak bermakna karena $\mathrm{p}>0,05$ dengan demikian dinyatakan bahwa suhu rumah bukan merupakan faktor risiko kejadian Tuberkulosis Paru atau tidak ada hubungan yang signifikan antara suhu dengan kejadian Tuberkulosis Paru.

Penelitian yang telah dilakukan di Wilayah kerja Puskesmas I Cilongok bahwa mayoritas suhu rumah responden memenuhi syarat dengan suhu nyaman $18^{\circ} \mathrm{C}-30^{\circ}$. Hal ini dikarenakan letak geografis daerah Cilongok bukan dataran tinggi dan suhu rata-rata harian $28^{0} \mathrm{C}$. Suhu optimum pertumbuhan Mycobacterium tuberculosis pada $37^{\circ} \mathrm{C}$ dan $\mathrm{pH}$ optimum 6,4 sampai 7 (Ulfah Ikrami, 2013), sehingga bakteri ini tidak dapat tumbuh subur di Wilayah Puskesmas I Cilongok dan bakteri tersebut sulit untuk tumbuh pada suhu dibawah $25^{\circ} \mathrm{C}$ dan diatas $41^{\circ} \mathrm{C}$ (Microbe Wiki, 2011).

Hasil penelitian ini sesuai dengan penelitian yang telah dilakukan oleh Anggie Mareta Rosiana (2012) dengan $p$ value $=0,337$ yang artinya tidak ada hubunganantara suhu rumah responden dengan kejadian Tuberkulosis Paru.

Pada penelitian Case Control ini memiliki kelemahan bias karena faktor risiko dan efek tidak diidentifikasi secara bersamaan. Seperti perubahan suhu saat terjadinya paparan berbeda dengan saat dilakukan identifikasi efek, hal ini disebabkan bahwa perubahan suhu terjadi karena perubahan aliran panas dan usaha yang dilakukan (Aris Santjaka, 2013).

\section{Luas Ventilasi}

Ventilasi dalam rumah berfungsi sebagai sirkulasi udara atau pertukaran udara dalam rumah karena udara yang segar dalam ruangan sangat dibutuhkan manusia. Ventilasi yang buruk akan menimbulkan gangguan kesehatan pernapasan pada penghuninya. Pertukaran penyakit saluran pernapasan disebabkan karena kuman didalam rumah tidak bisa tertukar sehingga ventilasi diharuskan memenuhi syarat Menkes RI No.1077/MENKES/PER/V/2011 yaitu luas ventilasi minimal $10 \%$ dari luas lantai.

Dalam penelitian ini proporsi kasus yang luas ventilasi rumahnya tidak memenuhi syarat/ $<10 \%$ luas lantai pada kelompok kasus (20\%) lebih besar dibanding pada kelompok kontrol (10\%). Secara statistik hasil analisa menunjukkan $\mathrm{p}=0,472$ dan $\mathrm{OR}=2,250$ dengan $\mathrm{CI}$ $95 \%=0,507<\mathrm{OR}<9,993 \quad$ sehingga tidak bermakna karena $\mathrm{p}>0,05$ dengan demikian dinyatakan bahwa luas ventilasi rumah bukan merupakan faktor risiko kejadian Tuberkulosis Paru atau tidak ada hubungan yang signifikan antara luas ventilasi dengan kejadian Tuberkulosis Paru.

Pengaruh buruk berkurangnya ventilasi adalah berkurangnya kadar oksigen, bertambahnya kadar gas CO2, adanya bau pengap, suhu udara ruangan naik, dan kelembaban udara ruangan bertambah (Mukono, 2000:156). Hal tersebut bisa menjadi faktor risiko terjadinya Tuberkulosis karena bakteri tuberkulosis dapat bertahan hidup dalam waktu lama di tempat yang gelap dan lembab (Th.Erlien, 2008: 42). Berdasarkan hasil penelitian di lapangan didapatkan hasil bahwa (15\%) luas ventilasi rumah responden tidak memenuhi syarat. Hal ini dikarenakan ventilasi yang ada di rumah responden tidak digunakan dengan semestinya, misalnya jendela yang dibiarkan selalu tertutup dan tidak dibiasakan untuk membuka jendela setiap pagi, sehingga sebagian besar jendela pada rumah responden bukan termasuk ventilasi dan tidak diukur dalam penelitian ini, begitu juga luas ventilasi sebagian besar belum memenuhi syarat yaitu $10 \%$ dari luas lantai. Sebaiknya responden harus memiliki kesadaran untuk membuka jendela setiap hari agar rumah tidak pengap karena sirkulasi udaranya bisa maksimal.

\section{Jenis Lantai}

Persyaratan rumah sehat memiliki lantai yang terbuat dari marmer, ubin, kramik dan sudah diplester semen tercantum dalam persyaratan kesehatan perumahan RI No.1077/MENKES/PER/V/2011. Jenis lantai juga menentukan suhu dan kelembaban rumah yang mempengaruhi pertumbuhan bakteri.

Pada penelitian ini didapatkan hasil observasi jenis lantai rumah responden sebagian besar tanah, ubin dan kramik. Jenis lantai yang tidak memenuhi syarat pada kasus dan kontrol sebanyak 12 dari 60 (20\%), sedangkan jenis lantai rumah responden yang memenuhi syarat sebanyak 48 dari 60 (80\%). Berdasarkan hasil chi-square didapatkan bahwa nila $p=0.333$, OR=2,364 dan CI $95 \%=0,627<\mathrm{OR}<8,917$ yang artinya dapat disimpulkan bahwa tidak ada hubungan antara jenis lantai rumah responden terhadap kejadian penyakit Tuberkulosis Paru di Wilayah Kerja Puskesmas I Cilongok.

Hasil observasi lapangan jenis lantai responden sebagian besar sudah memenuhi syarat/ kedap air baik berbahan semen,tehel atau keramik namun lantai rumah tersebut tidak dibersihkan secara teratur sehingga banyak debu yang 
menempel. Lantai yang baik adalah lantai yang dalam kondisi kering dan tidak lembab dan harus kedap air sehingga mudah dibersihkan, rumah yang tidak baik mempunyai lantai yang terbuat dari tanah cenderung menimbulkan debu yang berbahaya bagi penghuni rumah(Ditjen FFM dan FL 2002).

Hasil penelitian ini sesuai dengan penelitian Annisa Febriana Siregar (2015) dengan p value= 0,190 maka dapat disimpulkan tidak terdapat hubungan antara jenis lantai dengan kejadian Tuberkulosis Paru

\section{Jenis Dinding}

Dinding berfungsi sebagai pelindung rumah yang terbuat dari berbagai bahan seperti bambu, triplek, batu bata dan dari bahan tersebut yang paling baik yaitu yang terbuat dari batu bata atau tembok.

Pada penelitian ini didapatkan hasil jenis dinding rumah responden yang tidak memenuhi syarat pada kasus dan kontrol sebanyak 24 dari 60 (40\%), sedangkan jenis dinding responden yang memenuhi syarat sebanyak 36 dari 60 (60\%). Hasil chi-square nilai $p=0,792$ yang artinya Ho diterima, sehingga dapat disimpulkan bahwa tidak ada hubungan antara jenis dinding rumah responden terhadap kejadian pneumonia di Wilayah Puskesmas I Cilongok. Hasil nilai OR sebesar 1,321, CI $95 \%=0,469<\mathrm{OR}<3,721$ yang berarti bahwa jenis dinding rumah bukan faktor risiko kejadian penyakit Tuberkulosis. Hal ini terjadi karena sebagian besar rumah responden menggunakan jenis dinding yang terbuat dari tembok namun tidak sedikit juga rumah responden yang jenis dinding rumahnya belum memenuhi syarat tetapi hasil dari uji statistik menunjukan bahwa tidak ada hubungan yang signifikan antara jenis dinding dengan kejadian penyakit Tuberkulosis Paru.

Penelitian ini sesuai dengan Borneo Yuda Pratama (2012) yang menyatakan bahwa tidak ada hubungan antara jenis dinding rumah responden terhadap kejadian penyakit Tuberkulosis Paru. Sesuai dengan Kepmenkes No.829 tahun 1999 tentang Persyaratan Kesehatan Perumahan jenis dinding yang baik adalah kedap air.

\section{Kepadatan Penghuni}

Persyaratan kepadatan hunian untuk rumah sehat tercantum dalam persyaratan kesehatan perumahan RI No.1077/MENKES/PES/V/2011. Rumah dikatakan padat atau tidak memenuhi syarat apabila luas rumah dibagi penghuni adalah $<10 \mathrm{~m}^{2}$.

Pada penelitian ini didapatkan hasil kepadatan hunian rumah yang tidak memenuhi syarat pada kasus dan kontrol sebanyak 5 dari 60 (27,9\%), sedangkan kepadatan hunian rumah yang memenuhi syarat sebanyak 55 dari 60 (72,1\%). Hasil uji chi-square nilai $\mathrm{p}=0,100$ yang artinya Ho diterima, sehingga dapat disimpulkan bahwa tidak ada hubungan antara kepadatan penghuni rumah terhadap kejadian penyakit Tuberkulosis Paru di Wilayah Kerja Puskesmas I Cilongok. Hasil nilai OR sebesar 0,643 (95\% CI= 0,100-4,153) yang berarti bahwa kepadatan penghuni rumah bukan faktor risiko kejadian penyakit Tuberkulosis Paru.

Kepadatan penghuni ini dinilai dengan luas rumah dibagi dengan jumlah penghuni rumah. Sebagian besar rumah responden pada penelitian ini hanya dihuni oleh keluarga kecil dengan jumlah individu $3-5$ orang. Hal ini mempengaruhi hasil perhitungan dimana nilai kepadatan hunian memenuhi kriteria syarat rumah sehat.

Pada aspek kepadatan penghuni menunjukkan bahwa sebagian besar responden penelitian, baik pada kasus maupun kontrol, tinggal pada kamar tidur yang tergolong tidak padat penghuni. Tiap kamar rata-rata dihuni oleh 2 orang dengan luas kamar yang sebagian besar sudah memenuhi syarat yaitu $8 \mathrm{~m} 2$ atau lebih. Dengan demikian responden kasus maupun kontrol mempunyai peluang yang sama untuk terpapar dan menderita TB paru. Hal ini menyebabkan adanya kesamaan keadaan kepadatan penghuni antara responden kasus dan responden kontrol. Hasil statistik juga menunjukkan tidak ada hubungan antara kepadatan penghuni dengan kejadian Tuberkulosis Paru.

Menurut Kepmenkes RI No. 829/ Menkes/SK/VII/1999 tentang persyaratan kesehatan perumahan, untuk pengukuran rumah sederhana, luas kamar tidur minimal $8 \mathrm{~m} 2$ dan dianjurkan tidak untuk lebih dari 2 orang. Rumah dikatakan padat/ tidak memenuhi syarat apabila luas rumah dibagi penghuni adalah $<10 \mathrm{~m}^{2}$.

Kepadatan penghuni dikategorikan memenuhi standar (2 orang per $8 \mathrm{~m} 2$ ) dan kepadatan tinggi (lebih dari 2 orang per $8 \mathrm{~m} 2$ dengan ketentuan anak $<1$ tahun tidak diperhitungkan dan umur 1-10 tahun dihitung setengah) (Mukono, 2000:156).

Kepadatan penghuni menentukan insidensi penyakit maupun kematian, terutama di negara Indonesia yang masih banyak sekali terdapat penyakit menular, seperti penyakit pernapasan dan semua penyakit yang menyebar lewat udara misalnya tuberkulosis menjadi mudah sekali menular (Juli Soemirat, 2000:144).

Dari survei di lapangan dalam rumah responden rata-rata tiap kamar dihuni oleh 2 sampai 3 orang, yaitu dihuni suami dan istri atau dengan anaknya. Ada juga yang 1 kamar dihuni hanya 1 orang saja, sehingga kemungkinan besar Tuberkulosis Paru tidak dipengaruhi oleh kepadatan penghuni. 


\section{Analisis Multivariat}

Hasil analisis multivariat menggunakan uji regresi logistik, menunjukan bahwa kontak penderita dan status gizi merupakan faktor yang paling berpengaruh terhadap kejadian Tuberkulosis Paru, ditunjukan dengan besar nilai p yaitu 0,000 dan 0,004 .

Hasil uji multivariat penelitian ini sesuai dengan hasil penelitian Dwi Purnomo Sidhi (2010), yang mengatakan bahwa kontak dengan penderita Tuberkulosis merupakan faktor risiko utama dan makin erat kontak makin besar risikonya. Oleh karenanya kontak di rumah dengan anggota keluarga yang sakit Tuberkulosis sangat berperan untuk terjadinya infeksi Tuberkulosis di keluarga, terutama keluarga terdekat. Faktor lain adalah jumlah orang serumah (kepadatan hunian), lamanya tinggal serumah dengan pasien, pernah sakit TB dan satu kamar dengan penderita TB di malam hari, terutama bila satu tempat tidur.

Hasil uji statistik multivariat ini juga sesuai dengan hasil analisis data menggunakan uji regresi logistik bergandaMohammad Harianto (2014), menunjukkan bahwa variabel kontak dengan penderita Tuberkulosis memiliki nilai signifikansi p $(0,001)<0,05 ; 95 \%$ CI: $>1$, sehingga variabel kontak dengan penderita Tuberkulosis dapat dikatakan variabel yang paling berpengaruh signifikan terhadap kejadian Tuberkulosis. Variabel tingkat konsumsi lemak memiliki nilai signifikansi p $(0,024)<0,05 ; 95 \%$ CI: > 1 sehingga variabel tingkat konsumsi energi berpengaruh signifikan terhadap kejadian Tuberkulosis dan variabel tingkat konsumsi lemak memiliki nilai signifikansi p $(0,022)<0,05 ; 95 \%$ CI: $<1$ sehingga variabel tingkat konsumsi lemak merupakan faktor protektif terhadap kejadian Tuberkulosis. Variabel status gizi memiliki nilai signifikansi p $(0,013)<0,05 ; 95 \%$ CI: $>1$ sehingga variabel status gizi berpengaruh signifikan terhadap kejadian TB.

Secara etiologi penyakit tuberkulosis, kuman Mycobacterium tuberculosis berukuran sangat kecil, bersifat aerob, dapat bertahan hidup lama dalam sputum kering, ekskreta lain dan dengan mudah dapat dieksresikan melalui inhalasi butir sputum lewat batuk, bersin maupun bicara (droplet infection), sehingga kontak yang sering dengan penderita tuberkulosis aktif akan menyebabkan infeksi atau paparan paparan orang yang sehat. Kontak dengan penderita adalah tinggal bersama dalam rumah yang sama atau frekuensi sering bertemu antara kontak dengan sumber penular (Afiyah Sri Harnani, 2013). Penderita TBC dapat menularkan secara langsung terutama pada orang di lingkangan rumah, masyarakat di sekitarnya dan lingkungan tempat bekerja, makin meningkatnya waktu berhubungan dengan penderita memberi kemungkinan infeksi lebih besar pada kontak.

Faktor kedua yang paling berpengaruh terhadap kejadian penyakit Tuberkulosis Paru setelah kontak penderita adalah status gizi.Hasil analisis statistik bivariat maupun multivariat menunjukkan bahwa faktor status gizi mempunyai hubungan yang signifikan dengan kejadian tuberkulosis paru karena $\mathrm{p}<0,05$ pada analisis bivariat diperoleh hasil $\mathrm{p}=0,009$ OR $=$ 4,667dengan $\quad$ CI $\quad 95 \%=\quad 1,571<\mathrm{OR}<13,868$. Artinya status gizi $<18,5$ mempunyai risiko terhadap kejadian tuberkulosis paru sebanyak 4,667 kali lebih besar dibanding dengan status gizi $\geq 18,5$. Hal ini sesuai dengan penelitian Siti Fatimah (2008) yang menunjukkan bahwa orang dengan $\mathrm{BMI}<18,5$ mempunyai risiko 2,737 kali lebih besar untuk menderita TB paru dibanding orang dengan $\mathrm{BMI} \geq 18,5$.

\section{Simpulan dan Saran \\ Simpulan}

Faktor yang mempengaruhi kejadian penyakit Tuberkulosis Paru yaitu status gizi (OR $=4,667$, nilai-p $=0,009)$, kontak penderita $(\mathrm{OR}=$ $9,333$, nilai-p $=0,000)$ dan pencahayaan $(\mathrm{OR}=$ 3,455 , nilai-p $=0,038$ ).

Berdasarkan ketiga faktor yang mempunyai risiko terhadap kejadian Tuberkulosis paru, faktor atau variabel yang paling berpengaruh terhadap kejadian Tuberkulosis Paru adalah variabel kontak penderita. Dari hasil analisis mulivariat kontak penderita mempunyai nilai ( $\mathrm{OR}=12,738$, nilai-p 0,000)

\section{Saran}

Penderita Tuberkulosis Paru harus menjaga kontak terhadap keluarga yang sehat yaitu mengurangi kontak dengan keluarga lainnya untuk sementara selama pengobatan guna mencegah penularan terhadap keluarga serumah atau lingkungan rumah dan menggunakan masker untuk mengurangi paparan droplet terhadap keluarga yang sehat.

Keluarga penderita Tuberkulosis Paru harus diberikan pemahaman bahwa keluarganya yang menderita Tuberkulosis Paru harus selalu diusahakan berada pada tempat yang memiliki ventilasi udara yang cukup, dinding dan lantai yang kedap air dan pencahayaan yang baik guna mengurangi risiko terjadinya keparahan penyakit Tuberkulosis Paru.

Melakukan upaya perbaikan gizi dengan cara memperhatikan pola makan yang baik, makan makanan kecil yang sederhana dan mudah dicerna sepanjang hari dengan rentang waktu yang singkat agar badan mendapat cukup asupan cairan dan garam dalam makanan, makan makanan yang kaya protein seperti kacangkacangan dan biji-bijian selain itu susu sebagai sumber kalsium, 
Rumah dengan pencahayaan tidak memenuhi syarat, penghuni rumah dapat melakukan penyehatan lingkungan rumah dengan cara membuka jendela rumah setiap pagi, menambah jumlah jendela dan mengganti genting menggunakan genting kaca yang bertujuan agar cahaya matahari dapat masuk ke rumah guna membunuh kuman-kuman Tuberkulosis dan meningkatkan kekebalan tubuh terhadap Mycobacterium tuberculosis melalui pengaktifan vitamin D dengan bantuan sinar matahari.

\section{DAFTAR PUSTAKA}

Afiyah Sri Harnany. 2013. Pengaruh Perilaku dan Status Gizi terhadap Kejadian TB Paru Di Kota Pekalongan. Pekalongan: Prodi Keperawatan Pekalongan, Politeknik Kesehatan Kemenkes Semarang.

Akbar. 2010. Faktor-Faktor Yang Berhubungan Dengan Kejadian Tbc-Paru di Wilayah Kerja Puskesmas Bolangitang Kabupaten Bolaang Mongondow Utara Tahun 2010. Bolaang: Universitas Gorontalo.

Anggie Mareta Rosiana. 2012. Hubungan Antara Kondisi Fisik Rumah Dengan Kejadian Tuberkulosis Paru di Wilayah Kerja Puskesmas Kedungmundu Kota Semarang. Semarang: Jurusan Ilmu Kesehatan Masyarakat, Fakultas Ilmu Keolahragaan, Universitas Negeri Semarang, Indonesia.

Annisa Febriana Siregar. 2015. Hubungan Kondisi Fisik Rumah Dan Pekerjaan Dengan Kejadian Tuberkulosis Paru Di Desa Bandar Khalipah Kecamatan Percut Sei Tuan Tahun 2015. Sumatra Utara: Fakultas Kesehatan Masyarakat USU Sumatera Utara.

Anwar Hidayat. 2012. Odd Ratio dalam SPSS. (Online).http://www.statistikian.com, diakses tanggal 22 Juni 2016 pukul 1926.

Aris Santjaka. 2011. Statistik Untuk Penelitan Kesehatan. Yogyakarta: Nuha Medika.

Aris Santjaka. 2013. Malaria Pendekatan Metode Kausalitas. Yogyakarta. Nuha Medika

Aristatika. 2011. Hubungan Faktor Lingkungan Fisik Rumah Dengan Kejadian Tuberkulosis Paru Di Wilayah Kerja Puskesmas Mrebet Purbalingga Tahun 2011. Purbalingga: Poltekes Kemenkes Semarang.

Borneo Yuda Pratama. 2012. Hubungan Karakteristik Lingkungan Fisik Rumah dengan Kejadian Tb Paru Di Wilayah Kerjapuskesmas Guntung
Payung. Banjarmasin: Ilmu Keperawatan Fakultas Kedokteran Universitas Lambung Mangkurat 2012.

Budiman Chandra. 2007. Pengantar Kesehatan Lingkungan. Jakarta: EGC.

Chandra W, Maria CH Winarti, H Mewengkang. 2004. Kasus Kontak Tuberkulosis Paru di Klinik Paru Rumah Sakit Umum Pusat Manado. Manado: Majalah Kedokteran Indonesia.

Debby Fadilah. Faktor-Faktor Resiko Kejadian Tuberkulosis. http://ilmuveteriner. Diakses 18 Desember 2015 pukul 21.20.

Dewi Yuliyati, 2010. Hubungan Perilaku Anggota Keluarga dengan Kejadian Penyakit TB Paru Di Kabupaten Banyumas 2009-2010. Banyumas: Poltekkes Kemenkes Semarang.

Dian Wahyu A. 2014. Faktor Risiko Komponen Fisik Rumah Terhadap Kejadian Pneumonia Di Desa Traji Kecamatan Parakan Kabupaten TemanggungTahun 2015. Temanggung: Poltekkes Kemenkes Semarang.

Djamaludin Ramlan dan Maisye Marlyn Kuhu. 2014. Penulisan Penelitian Eksplanatif. Purwokerto: UPT. Percetakan dan Penerbitan UNSOED Grendeng.

Djasio, Sanropie dkk. 1989. Pengawasan Penyehatan Lingkungan Permukiman. Jakarta : Departemen Kesehatan RI, Pusat Pendidikan Tenaga Kesehatan.

Dwi Purnomo Sidhi. 2010. Riwayat Kontak Tuberkulosis Sebagai Faktor Risiko Hasil Uji Tuberkulin Positif. Semarang: Program Pendidikan Dokter Spesialis I Ilmu Kesehatan Anak Universitas Diponegoro Semarang 2010.

Fatimah Siti. 2008. Faktor Kesehatan Lingkungan Rumah yang Berhubungan dengan Kejadian TB Paru di Kabupaten Cilacap (Kecamatan : Sidareja, Cipari, Kedungreja, Patimun, Gandrungmangu, Bantasari) Tahun 2008. Cilacap: Universitas Diponegor Semarang.

Gould D dan Brooker C. 2003. Mikrobiologi Terapaan Untuk Perawat. Jakarta : EGC.

Handoko Riwidoko. 2007. Statistik Kesehatan. Yogyakarta: Mitra Cendikia

Hasan Alatas. 2005. Buku Kuliah Ilmu Kesehatan Anak. Jakarta : Info Medika. 
Hiswani. 2007. Tuberkulosis Merupakan Penyakit Infeksi Yang Masih Menjadi Masalah Kesehatan Masyarakat. http//library.usu.ac.id, Diakses 11 September 2015 pukul 18.50.

Kementerian Kesehatan Republik Indonesia. 2013. Profil Kesehatan Indonesia Tahun 2013. Jakarta: Kementerian Kesehatan Republik Indonesia.

Kementerian Kesehatan Republik Indonesia. 2015. Rencana Strategis Kementerian Kesehatan Tahun 2015-2019. Jakarta: Kementerian Kesehatan Republik Indonesia.

Mohammad Harianto. 2014. Pengaruh Kontak Dengan Penderita Tb, Konsumsi Makan Dan Faktor Lingkungan Fisik Rumah Terhadap Kejadian Tb 2014. Jember: Universitas Jember.

Muhammad Aandi Ihram. 2013. Hubungan Tingkat Sirkulasi Oksigen dan Karakteristik Individu dengan Kejadian Tb Paru Pada Kelompok Usia Produktif Di Puskesmas Pondok Pucung Tahun 2013. Fakultas Kesehatan Masyarakat, Universitas Islam Negeri Syarif Hidayatullah Jakarta.

Niko Rianda P. 2011. Hubungan Perilaku Dan Kondisi Sanitasi Rumah Dengan Kejadian Tb Paru Di Kota Solok Tahun 2011. Solok: Universitas Andalas.

Notoadmojo S. 2002, Promosi Kesehatan dan Ilmu Perilaku, Jakarta : Rineka Cipta

Notoatmodjo S. 2003, Ilmu Kesehatan Masyarakat, Prinsip - prinsip Dasar. Jakarta: Rineka Cipta.

Notoatmodjo S. 2007. Promosi Kesehatan dan Ilmu Perilaku. Jakarta : Rineka Cipta.

Nurhidayah, Ikue, Mamat Lukman, Windy Rakhmawati. 2007. Hubungan Karakteristik Lingkungan Rumah Dengan Kejadian Tuberkulosis (Tb) Pada Anak. Bandung : Fakultas Ilmu Keperawatan, Universitas Padjadjaran.

Nyoman Kandun I. 2006. Manual Pemberantasan Penyakit Menular. Jakarta: Info Medika.

Rosmayudi. 2002. Diagnosis dan Pengobatan Tuberkulosis pada Bayi dan Anak. (Online). http://www.depkes.com, diakses tanggal 26 Mei 2016 pukul 20.31.

Ruslanti Sianturi. 2013. Analisis Faktor Yang Berhubungan Dengan Kekambuhan Tb Paru (Studi Kasus Di Balai Kesehatan Paru
Masyarakat (Bkpm) Semarang Tahun 2013).

Semarang: Universitas Negeri Semarang.

Ruswanto, Bambang. 2010. Analisis Spasial Sebaran Kasus Tuberkulosis Paru ditinjau dari Faktor Lingkungan Dalam dan Luar Rumah di Kabupaten Pekalongan. Pekalongan: Universitas Diponegoro Semarang.

Setiawan Dwi Antoro. 2010. Hubungan Faktor Lingkungan Fisik Rumah dan Respons Terhadap Praktik Pengobatan Strategi DOTS Dengan Penyakit Tb Paru di Tirto Kabupaten Pekalongan Tahun 2010. Pekalongan: Jurnal Kesehatan Lingkungan Indonesia Vol. 11 No. 1 / April 2012.

Siti Fatimah. 2008. Faktor Kesehatan Lingkungan Rumah Yang Berhubungan Dengan Kejadian Tb Paru Di Kabupaten Cilacap (Kecamatan : Sidareja, Cipari, Kedungreja, Patimuan, Gandrungmangu, Bantarsari) Tahun 2008. Cilacap: Program Pasca Sarjana Universitas Diponegoro Semarang 2008

Suara Merdeka. 2015. Penderita Tuberculosis Cenderung

Meningkat. http://berita.suaramerdeka.com, Diakses 23 September 2015 pukul 19.45.

Suyono, Budiman. 2011. Ilmu Kesehatan Masyarakat Dalam Konteks Kesehatan Lingkungan tahun. Jakarta: EGC.

Yuyun Ayunnah. 2008. Hubungan antara faktorfaktor kualitas fisik rumah dengan kejadian TB Paru BTA Positif di Kecamatan Cilandak Kotamadya Jakarta Selatan. http://lib.ui.ac.id, diakses 28 Januari 2016 pukul 19.46. 